УДК 7/023/1-035/3:621.91/.92:378(477.54)

ХДАДМ
Босий Іван Михайлович,

кандидат мистецтвознавства, викладач кафедри «Дизайн інтер'єру і меблів»

Харківської державної академії дизайну і мистецтв

ORCID 0000-0001-8656-0604

Брижаченко Наталія Сергіївна, кандидат мистецтвознавства, доцент, доцент кафедри «Дизайн» Запорізького національного технічного університету

ORCID 0000-0001-7322-1291

Bryzhachenko@gmail.com

\title{
ТЕХНОЛОГІЇ СТВОРЕННЯ АРТ-ОБ'ЄКТІВ 3 ДЕРЕВИНИ (НА ПРИКЛАДІ РОБІТ СТУДЕНТІВ КАФЕДРИ ДИЗАЙНУ СЕРЕДОВИЩА ХДАДМ)
}

Мети роботи полягає у висвітленні досвіду створення творчих композицій з деревини на основі аналізу студентських робіт, виконаних під час навчального процесу у Харківській державній академії дизайну і мистецтв. Методологія роботи базується на комплексному поєднанні емпіричних та теоретичних методів пізнання. Створення арт-об'єктів з деревини має експериментальний характер, що виражається в унікальності кожної роботи та їх спрямованості на пошук нових засобів художньої виразності при роботі з деревиною. Тому емпіричні методи, а саме експеримент, порівняння та спостереження, при дослідження особливостей виготовлення означених творчих композицій, є основоположними. Для підсумків практичного досвіду та оновлення навчальної програми застосовуються теоретичні методи дослідження, а саме аналіз, узагальнення та прогнозування. Наукова новизна роботи полягає в узагальненні та систематизації практичного досвіду створення арт-об’єктів 3 деревини. Висновки: встановлено, що створення творчих композицій з деревини спирається не лише на знаннях 3 композиції, а й на розуміння особливостей роботи сучасного промислового обладнання, яке застосовується при створенні означених арт-об'єктів; виявлено, що використання інноваційних технічних засобів передбачає вміння та навички роботи студентів в спеціальних графічних комп'ютерних програмах та розуміння фізичних та художньо-естетичних властивостей матеріалів (деревини, фанери).

Ключові слові: арт-об’єкти, арт-дизайн, деревина, фанера, моделювання, фрезерування.

Босый Иван Михайлович, кандидат искусствоведения, преподаватель кафедры дизайна среды Харьковской государственной академии дизайна и искусств; Брыжсаченко Наталья Сергеевна, кандидат искусствоведения, доцент кафедры дизайна Запорожского национального технического университета. среды ХГАДИ)

Технология создания арт-объектов из дерева (на примере работ студентов кафедры дизайна

Цель работы заключается в освещении опыта создания творческих композиций из древесины на основе анализа суденческих работ, выполненных во время учебного процесса в Харьковской государственной академии дизайна и искусств. Методология работы базируется на комплексном применении эмпирических и теоретических методов исследования. Создание арт-объектов из древесины имеет экспериментальный характер, что выражается в уникальности каждой работы и их направленности на поиск новых средств художественной выразительности при работе с древесиной. Поэтому эмпирические методы, а именно эксперимент, сравнение и наблюдения, при исследовании особенностей изготовления указанных творческих композиций, являются основополагающими. Для подведения итогов практического опыта и обновления учебной программы применяются теоретические методы исследования, а именно анализ, обобщение и прогнозирования. Научная новизна работы заключается в обобщении и систематизации практического опыта создания арт-объектов из древесины. Выводы: выявлено, что создание творческих композиций из древесины опирается не только на знаниях по композиции, но и на понимании особенностей работы современного промышленного оборудования, которое используется при создании указанных арт-объектов; установлено, что использование инновационных технических средств предполагает умение и навыки работы студентов в специальных графических компьютерных программах, понимание физических и художественно-эстетических свойств материалов (древесины, фанеры).

Ключевые слова: арт-объекты, арт-дизайн, древесина, фанера, моделирование, фрезерования.

Bosyi Ivan, Candidate of Science. Lecturer, Department of Design Environment, Kharkiv State Academy of Design and Arts; Bryzhachenko Natalia, Candidate of Science. Associate Professor, Department of Design, Zaporizhzhia National Technical University

(C) Босий I. М., 2019

(C) Брижаченко Н. С., 2019 
The technologies of the wooden art-objects creations (based on the example of the student's works of the environment design department of KNADA)

The purpose of the article is to highlight the experience of the creation of wooden art-objects. The analysis based on the review of the student's works performed during the educational process at the Kharkiv State Academy of Design and Arts. The methodology of this work based on the complex application of empirical and theoretical research methods. The creation of wooden art-objects has an experimental nature, which expressed in the uniqueness of each work and their focus on the search for new means of artistic expression during the work with wood. Therefore, empirical methods, namely experiment, comparison, and observation, when studying the characteristics of the manufacture of these creative compositions, are fundamental. To summarize the practical experience and update the curriculum applied theoretical research methods, namely analysis, synthesis, and forecasting. The scientific novelty of the work consists of summarizing and systematizing the practical experience of creating art objects from wood. Conclusions: it was revealed that the creation of wooden art objects is based not only on the knowledge of the composition but also on the understanding of the features of the work of modern industrial equipment, which is used to create these art objects. It was found that the use of innovative technical means involves the ability and skills of students in special graphics computer programs, an understanding of the physical and artistic and aesthetic properties of materials (wood, plywood).

Key words: art objects, art design, wood, plywood, modeling, milling.

Актуальність теми дослідження. Дослідження чисельних прикладів дизайну житлового та громадського інтер'єру дозволяє стверджувати, що наразі прослідковується тенденція включення різноманітних арт-об'єктів в загальне рішення предметно-просторового середовища. Як свідчить світова дизайн-практика, означені творчі композиції можуть бути як акцентними елементами інтер'єру, так і ставати композиційною домінантою простору.

Складність арт-об'єктів та їх якість залежать від вірності виконання всіх етапів створення роботи: від гармонійної композиції до фінальної роботи у матеріалі.

Поява такого напрямку як арт-дизайн відкрила горизонти для творчих експериментів та пошуків нових засобів художньої виразності різноманітних технік та матеріалів. Безперечно, одним 3 найбільш поширених матеріалів, з якого виконуються арт-об'єкти, є деревина. Розвиток технологій надає можливість створювати складні композиції, що відіграють роль змістовного центру середовища. Проте, необхідно відзначити, що відсутність знань з особливостей роботи сучасного обладнання не дозволяє дизайнерам підготувати свої ескізні пропозиції для їх практичного виготовлення в матеріалі. Розроблена у ХДАДМ методика створення арт-об'єктів з деревини поєднує знання 3 композиції, що є першочерговим завданням в процесі підготовки дизайнерів, навички підготовки макетів своїх арт-об'єктів для їх подальшого виготовлення на промисловому обладнанні та роботу з матеріалами. Відсутність подібних апробованих в педагогічній практиці методик роботи 3 матеріалами обумовлює актуальність роботи.

Аналіз останніх досліджень і публікацій. Дослідження появи такого напрямку як арт-дизайн та висвітлення основних напрямків створення сучасних арт-об'єктів здійснив український науковець О. Бойчук [2]. Автор зазначив, що терміном арт-дизайн «почали позначати підкреслено художні моделі об'єктів, що створювались на перетині авангардного мистецтва та дизайну, які йшли напереріз естетиці уніфіковано-модульних форм та конструкцій (...〉 » $[2,192]$. О. Бойчук дослідив розвиток арт-дизайну, зазначив основних діячів та виявив різноманіття напрямків даного явища постмодернізму. Автор зазначає, що початком арт-дизайну стали експерименти дадаїстів початку XX сторіччя (М. Дюшан. М. Рей), які продовжились в мистецтві інсталяції (С. Далі, Г. Мур та ін..) та творчості майстрів кінетичного мистецтва (О. Колдер, Ж. Тенглі та ін..).

Світова практика свідчить, що арт-дизайн від художніх експериментів 3 формою та матеріалами у концептуальних мистецьких творах, розповсюдився на предметно-просторове середовище. Дослідженнями арт-дизайну у проектуванні меблів кінця XX - початку XXI сторіч займалась М. Морозова [5]. Автор розглянула феномен арт-дизайну в меблях як особливий художньо-концептуальний напрямок проектної культури. При створенні об’єктів арт-дизайну на перший план виступає питання взаємодії мистецтва і дизайну, естетики та функціональності. Означена проблематика була розглянута в роботах В. Аронова [1], В. Глазичева [4], С. ХанМагамедов [7] та ін..

Цікаві приклади створення різноманітних об'єктів з деревини, в рамках навчального процесу, прослідковується у спадщині Вищих художньо-технічних майстерень та Вищого художньотехнічного інституту. Практичне ознайомлення з матеріалами та створення різноманітних творчих об'єктів надавало студентам можливість виявити не лише конструктивні особливості, а й художньоестетичні якості матеріалів. 
Серед публікацій, в яких здійснено огляд технологій обробки деревини, змістовними є роботи Дж. Брауна, в якій наведено основні методи обробки деревини [3].

Мета статті - висвітлення досвіду створення творчих композицій з деревини на прикладі студентських робіт, виконаних під час навчального процесу у Харківській державній академії дизайну і мистецтв (за період з 2014 по 2019 роки).

Виклад основного матеріалу. Розробка завдання «Творча композиція 3 деревини» була спрямована на оновлення практичного курсу дисципліни «Робота в матеріалі», яка викладається на 1 курсі кафедри «Дизайн середовища» у ХДАДМ. Зміна програми була зумовлена необхідністю ознайомлення студентів 3 новими можливостями роботи 3 деревиною в сфері дизайн-діяльності. 3 2014 по 2019 роки керівниками вказаної дисципліни були: Босий I.М., Брижаченко Н.С., Мироненко Н.Г., Педан І.В., Ставич Б.А., Черепанов К.М. та Конапльова О.В.

Проектна практика дизайнера інтер'єру і меблів безпосередньо пов'язана як зі знаннями матеріалів (іх конструктивними та художньо-декоративними властивостями), так і з сучасною промислово-технічною базою, певним інструментарієм, завдяки якому втілюються авторські задуми та створюється оригінальне предметне наповнення простору. Вміння професійно моделювати необхідні форми та підготувати електронні файли для промислового виробництва авторських об'єктів є важливим завданням в сучасній дизайнерській практиці. А знання та практичні навички 3 декоративної обробки дерев'яних поверхонь сприяють формуванню естетичної виразності об'єкту, його художньої цінності та самобутності.

Для навчального процесу стало необхідним дослідження світового досвіду створення артоб’єктів. Це дозволив зазначити, що творчі композиції можна класифікувати: за композиційною будовою: фронтальні, об'ємні, глибинно-просторові; за складовими елементами: модульні, подібні, різнорідні; за художньо-образним спрямуванням: абстрактні, асоціативні, натуралістичні (зображальні); за матеріалами: дерев'яні, полімерні, металеві, скляні, дзеркальні, з тканиною або комбіновані (поєднання в одній роботі декількох матеріалів); за функиією: створення композиційних акцентів або композиційної домінанти в інтер'єрі, вияв окремих зон у просторі, створення особливої художньо-образної системи в інтер'єрі.

Серед означених аспектів студентам було запропоновано створити фронтальні композиції, розміри яких мають складати 300x400 мм. Проте, слід зазначити, що вказані габарити творчих композицій не являють собою константу, оскільки, в залежності від авторського задуму, арт-об'єкт може мати будь-яку конфігурацію (компонуватись в квадрат, коло або більш складну геометричну форму). Також необхідно відмітити, що у 2015 році декілька студентів створили об'ємні композиції, які мали не лише декоративних характер, а й несли певне функціональне навантаження (органайзер для паперів, дзеркало). Додавання функціональності арт-об'єктам стало додатковим завданням для студентів, в результаті чого були розроблені авторські ключниці та світильники (нічники). Практика показала, що додавання штучного освітлення ускладнює конструктивну основу роботи, проте сприяє створенню цікавих декоративних ефектів.

За складовими елементами авторські композиції не обмежуються, що втілюється у варіативності художніх рішень та оригінальності поєднання форм у студентських роботах. Головним завданням залишається створення цілісної гармонійної композиції з урахування рельєфності та художніх особливостей матеріалу.

Під час навчального процесу підготовки дизайнерів інтер'єру і меблів у Харківській державній академії дизайну і мистецтв вирішується задача створення абстрактної творчої роботи на основі авторської композиції. Означені арт-об’єкти $\epsilon$ акцентами в предметно-просторовому середовищі, що передбачає розуміння понять про комбінаторику, декоративність та формоутворення.

Основним матеріалом виготовлення роботи є деревина (масив або фанера) 3 можливим акцентним додаванням інших матеріалів (метал, скло, дзеркало, кераміка, гіпс тощо). Властивості деревини дозволяють створювати різноманітні художні ефекти. Вміння власноруч працювати з таким матеріалом $\epsilon$ необхідною складовою професійної діяльності дизайнера інтер'єру та меблів.

Під час створення авторського арт-об'єкту студент поетапно ознайомлюється 3 основними технологіями обробки деревини: фрезерування, ошкурювання, різноманітні техніки оздоблювання дерев'яних поверхонь (маркетрі, інтарсія, інкрустація, обробка гарячим піском тощо) та склеювання. Таким чином, студент здійснює комплексну роботу з матеріалом.

Виконання означеного завдання передбачає розвинення композиційного мислення, оволодіння професійними навичками: ознайомлення 3 методикою формоутворення дерев'яних композицій, які застосовуються в дизайні середовища; розвинення творчого мислення; оволодіння навичками ремісничо-столярної роботи та варіативними техніками оздоблення дерев'яних поверхонь. 
Протягом навчального процесу студенти демонструють знання 3 теоретичних основ композиції та створюють арт-об'єкти 3 урахуванням досягнень в цій сфері художньої діяльності. Студенти на практиці засвоюють знання із властивостей та можливостей такого природнього матеріалу як деревина. Під час виготовлення авторського арт-об'єкту студенти не лише застосовують методи художньої обробки деревини,а й отримують знання з наявного виробничого інструментарію (ручного та промислового). В процесі роботи над творчою композицією студенти ознайомлюються 3 художніми та фізичними характеристиками різних порід деревини та фанери.

Створення авторського арт-об'єкту 3 деревини передбачає слідування певним етапам виконання твору:

1. Дослідження аналогів вже існуючих арт-об’єктів, виготовлених з різноманітних матеріалів (масив деревини, фанера, скло, метал, полімерні матеріали, вторинна сировина тощо). Сбір матеріалу дає змогу проаналізувати світові приклади створення різноманітних художніх творів. В процесі дослідження аналогів студент має звернути увагу на: композицію роботи, характерні моменти при обробці поверхонь, фактуру матеріалу, поєднання кількох різних матеріалів, пластика поверхонь.

2. Розробка ескізів творчих композищій здійснюється у графічних техніках, де враховуються всі аспекти створення гармонійної композиції. Після цього створюються макети у масштабі 1:2, що дозволяє розробити варіанти рельєфності фронтальної композиції, пропонуються фактурне оздоблення поверхонь та характер побудови об'ємної роботи.

3. Розробка макету в масштабі 1:1, яка дозволяє змоделювати всі бажані висоти, вигини та фактури, які запропоновано в роботі.

4. Створення комп'ютерних моделей арт-об’єктів. Виготовлення композиції з деревини передбачає застосування як ручного інструменту (лобзик, ручний фрезерний станок, прецизійний електролобзик тощо), так і вирізання деталей та основи роботи на промисловому обладнанні. При застосування промислових верстатів (лазерного або фрезерного 3 числовим програмним управлінням) постає необхідність підготовки макету в графічних програмах векторної графіки (CorelDraw) або 3d моделювання (Rhinoceros).

5. Виготовлення деталей та основи творчої композииї в матеріалі. Означений етап передбачає випилювання окремих елементів та бази роботи. Після випилювання елементів композиції необхідно обробити дерев'яні поверхні - ручна шліфовка або застосування вібраційної та стрічкової шліфувальних машин.

6. Декоративне оздоблення поверхонь дерев'яних елементів. Можливе застосування наступних технік: маркетрі, інтарсія, інкрустація, обробка гарячим піском, тонування, випалювання тощо.

7. Після декоративного оздоблення поверхонь композиції, необхідно склеїти елементи роботи в окремі блоки та форми.

8. Завершальною стадією створення творчої композииії з деревини є оформлення роботи, що передбачає додавання акцентних елементів з інших матеріалів (дзеркало, перламутр, скло, метал тощо) та приклеювання готових сегментів до основи композиції. За декілька років роботи на практиці студенти застосовували, окрім фанери, дерев'яні олівці та шпон різних порід деревини (Рис. 1 Рис.7). 


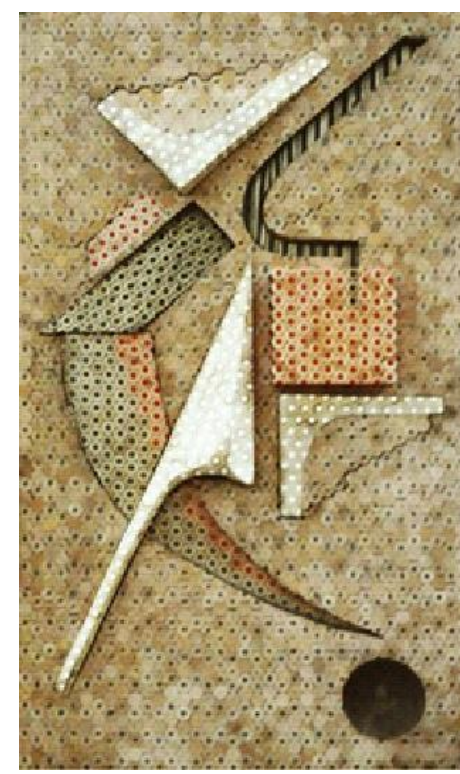

Рис. 1. Пасинок В. 2014 р. Кер. Брижаченко Н.С.

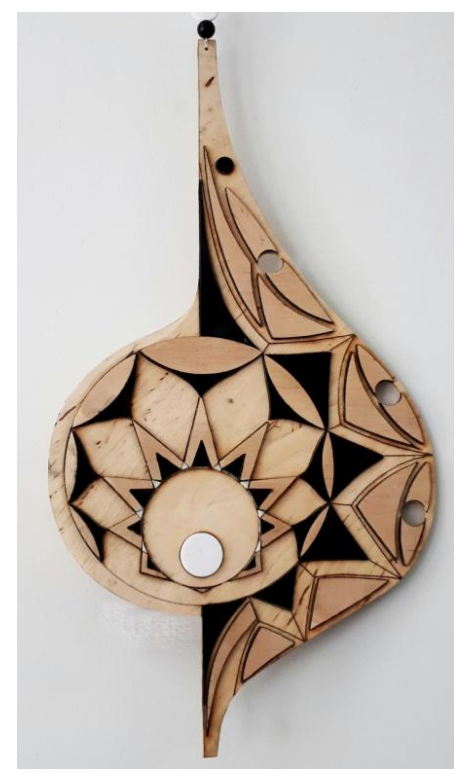

Рис.2. Матвесва Д. 2017 p. Кер. Брижаченко Н.С.

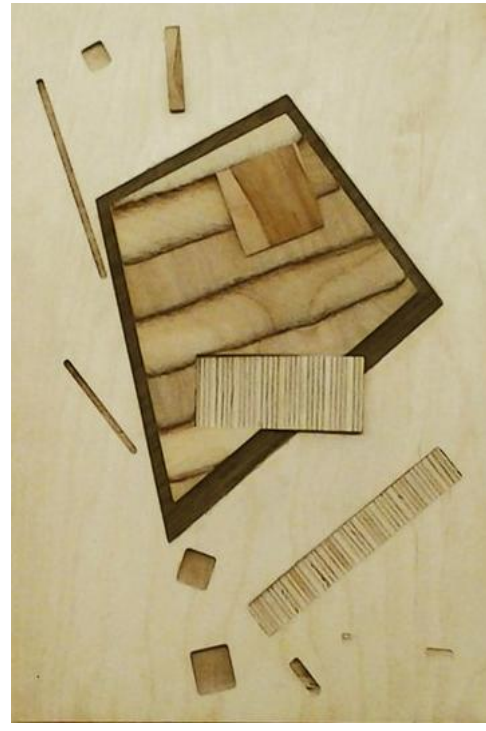

Рис.3. Ігнатюк С. 2014 p. Кер. Мироненко Н.Г.

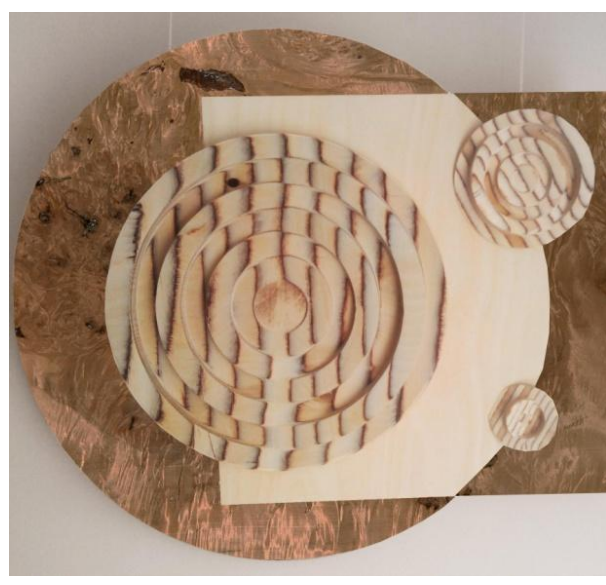

Puc. 4. Попова С. 2015 p. Кер. Брижаченко Н.С.

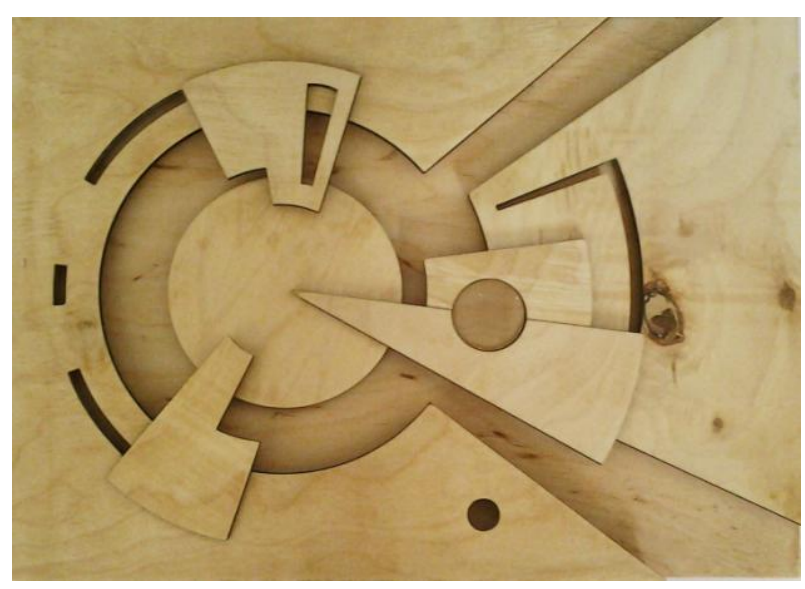

Рис.5. Нижник О. 2014 р. Кер. Брижаченко H.C. 


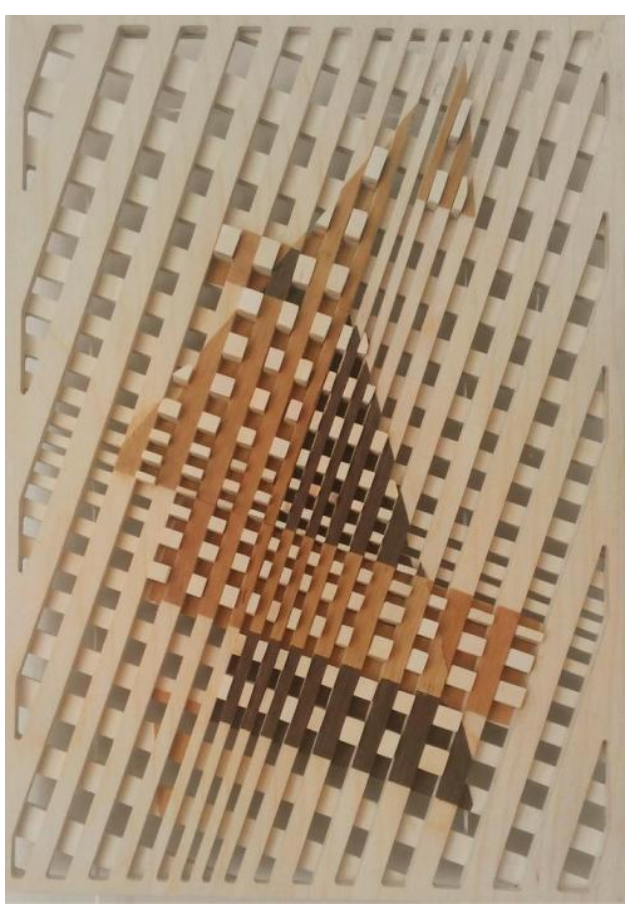

Рис.6. Образцова М. 2015 p. Кер. Босий I.M.

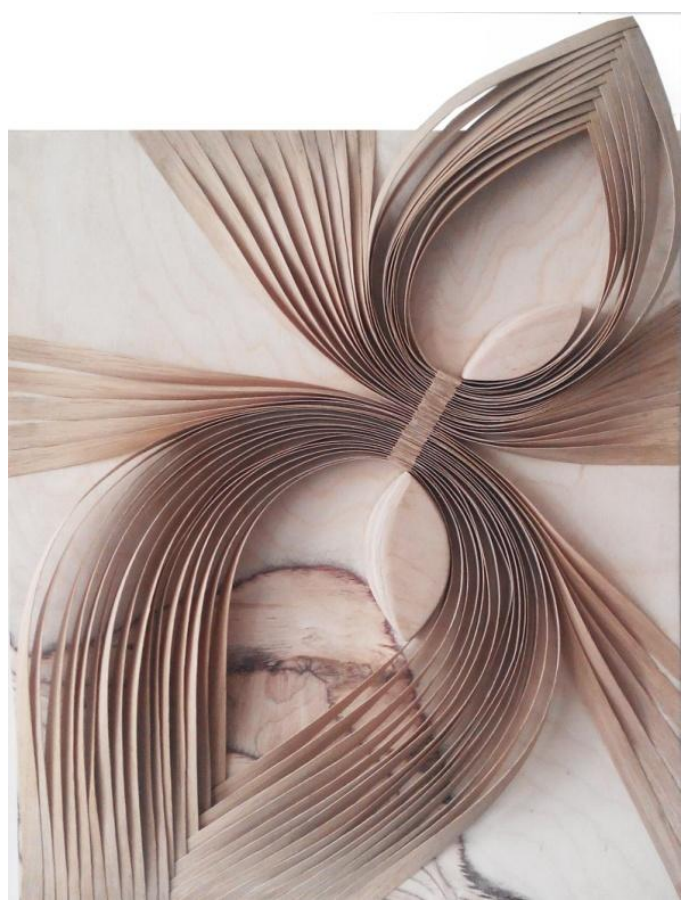

Рис.7. Водолазська П. Гнуття шиону. 2016 р. Кер. Педан I.В.

Проте. слід зазначити, що в процесі викладання даної дисципліни все частіше з'являються роботи, які являють собою повністю фрезеровані об'єкти, в яких відсутні склеєні додаткові елементи. Рельєф поверхонь та фактурне оздоблення форм досягається виключно завдяки $3 \mathrm{~d}$ моделюванню та фрезеруванню на обладнанні з ЧПУ (Рис.8, Рис.9).

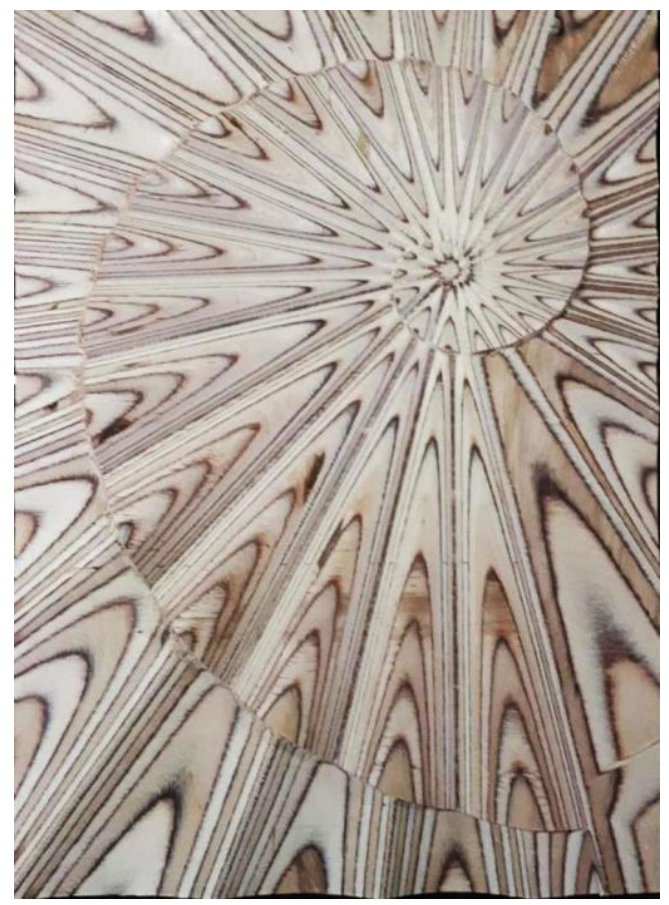

Рис.8. Швецова В. 2019 р. Кер. Босий I.М.

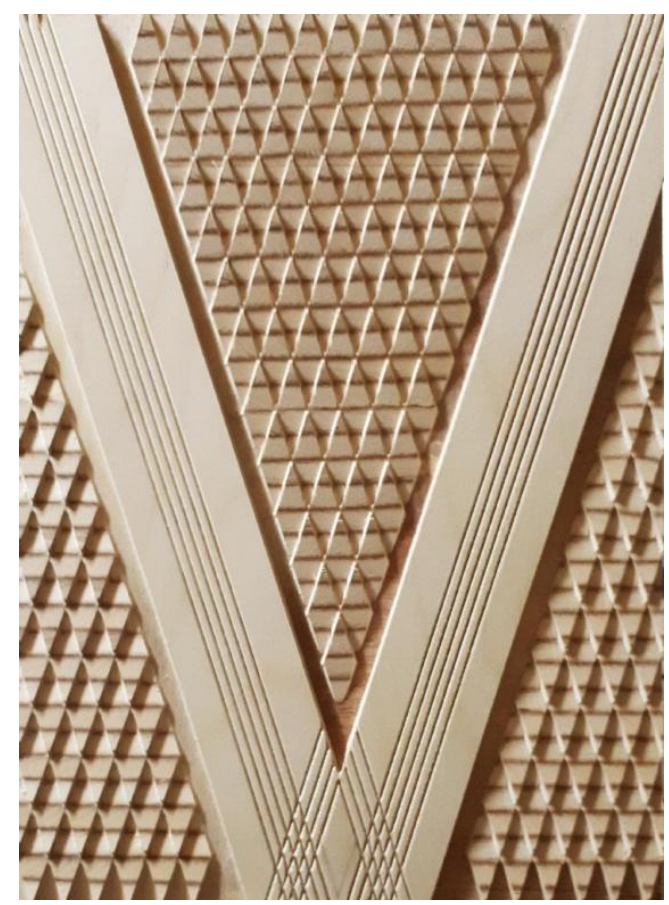

Рис.9. Оніщенко О. 2019 р. Кер. Босий І.М.

Окремо слід зазначити, що позитивні результати дало суміщення дерев'яного каркасу із декоративним штучним освітленням, коли арт-об'єкт починає виконувати функцію світильника. дзеркала або органайзера (Рис.10. - Рис.13). 


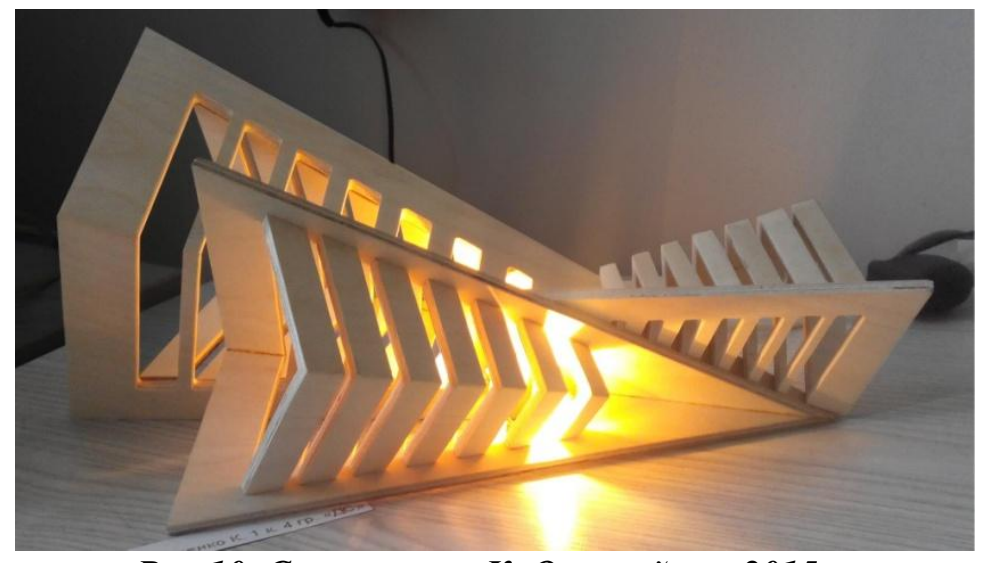

Рис.10. Степаненко К. Органайзер. 2015 р. Кер. Брижаченко Н.С.
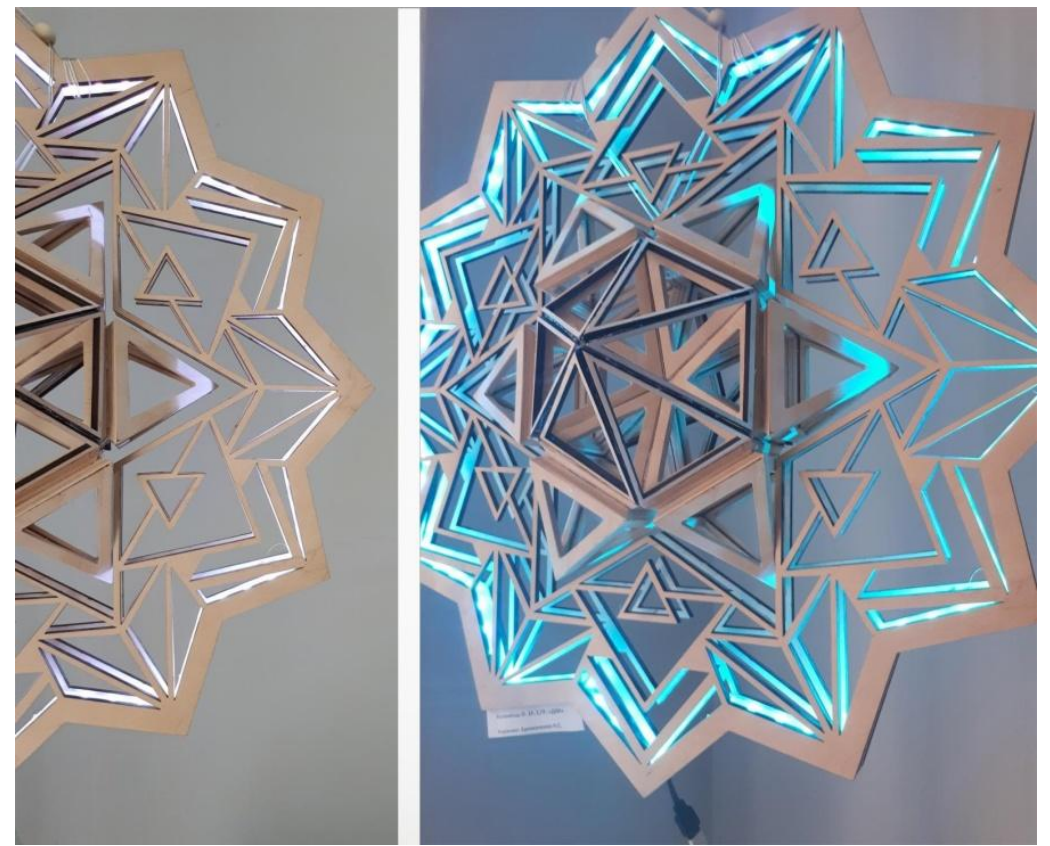

Рис.12. Коломійцева О. Нічник. 2017 р. Кер. Брижаченко Н.С.

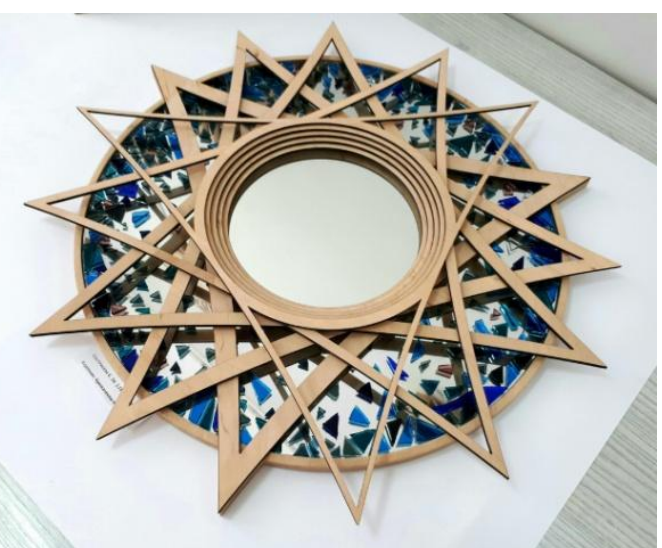

Рис.11. Свстегнєєва С. Дзеркало. 2017 p. Кер. Брижаченко Н.С.

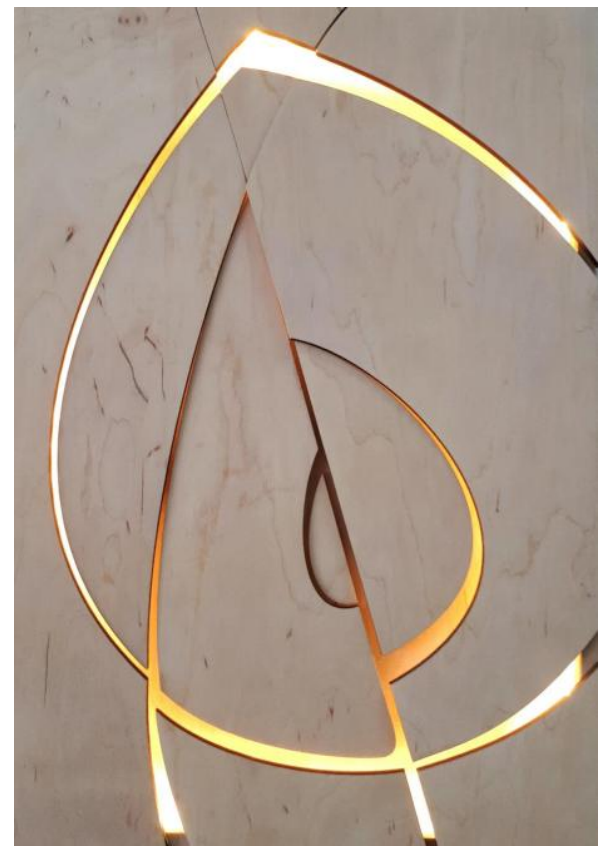

Рис.13. Криволапова Д. Настінний світильник. 2017 р. Кер. Брижаченко Н.С.

Наукова новизна роботи полягає в узагальненні та систематизації практичного досвіду створення арт-об'єктів 3 деревини (на прикладі студентських робіт Харківської державної академії дизайну і мистецтв).

Висновки. Досвід створення арт-об'єктів з деревини в рамках навчального процесу ХДАДМ показав, що виготовлення означених творів спирається не лише на знання 3 композиції, а й на розуміння особливостей роботи сучасного промислового обладнання, яке застосовується при створенні сучасних арт-об’єктів. Виявлено, що використання інноваційних технічних засобів передбачає вміння та навички роботи студентів в спеціальних графічних комп'ютерних програмах (векторної графіки та $3 \mathrm{~d}$ моделювання) та розуміння фізичних та художньо-естетичних властивостей матеріалів (деревини, фанери).

Як свідчить практика створення арт-об'єктів 3 деревини на кафедрі «Дизайн середовища» ХДАДМ, переважна більшість студентів застосовувала ЧПУ обладнання для виготовлення своїх творчих композицій в матеріалі. Активне використання промислового обладнання не нівелює ручне створення художніх творів, а спрямовано на оптимізацію процесу та відкриває нові можливості роботи 3 таким матеріалом, як фанера. Саме фанера стала основним матеріалом при створенні вищезазначених авторських арт-об' єктів. Вручну працювати 3 таким матеріалом не доцільно як 3 позиції затрат часу, так і з огляду на якість та варіативність обробки.

Досвід створення арт-об'єктів 3 деревини свідчить на користь впровадження в навчальний процес підготовки дизайнерів інтер'єру і меблів промислового обладнання. Це не лише підвищує 
якість створення об'єктів, а й наближує навчальний процес до реальних умов дизайн-діяльності, де вміння орієнтуватись в можливостях обладнання відкриває нові горизонти для створенні не лише артоб’єктів, а й різноманітного функціонального предметного наповнення середовища життєдіяльності людини.

\section{Jimepamypa}

1. Аронов В. Р. Дизайн в культуре XX века : анализ теорет. концепций : автореф. дис. . д-ра искусствоведения. М., 1995.38 с.

2. Бойчук А. В. Пространство дизайна. Харьков : Новое слово, 2013. 368 с

3. Браун Дж. Энциклопедия методов обработки дерева. АСТ, Астрель, 2005. 176 с.

4. Глазычев В. Л. Дизайн как он есть. Москва : Европа, 2006. 320 с.

5. Морозова М. А. Арт-дизайн в зарубежном проектировании мебели XX - начала XXI вв. : автореф. дис. ... канд. искусствоведения: 17.00.06 - техническая эстетика и дизайн. Санкт-Петербург, 2008. 26 с.

6. Фиелл Ш. Энциклопедия дизайна. Концепции. Материалы. Стили. Москва : Астрель, 2008. 192 с.

7. Хан-Магомедов С. О. К постановке вопроса о специфике художественной формы в дизайне. Проблемы художественной выразительности современной предметной среды. Тр. ВНИИТЭ. Сер. Техническая эстетика. Москва : ВНИИТЭ, 1985. Вып. 45. 100 с.

\section{References}

1. Aronov V. R. (1995) Design in the culture of the XX century: an analysis of theoretical concepts. Extended abstract of candidate's thesis. Moscow [in Russian].

2. Boychuk A. (2013). Design space. Kharkov: New Word [in Russian].

3. Brown J. (2005). Encyclopedia of wood processing methods. Ast, Astrel [in Russian].

4. Glazychev V. L. (2006). Design as it is. Moscow: Europe. (in Russian).

5. Morozova M. A. (2008) Art-design in the foreign furniture design of the XX - the beginning of the XXI centuries. Extended abstract of candidate's thesis. St. Petersburg [in Russian].

6. Fiell S. (2008) Design Encyclopedia. Concepts. Materials Styles. Moscow: Astrel [in Russian].

7. Khan-Magomedov S. O. (1985). On the question of the specifics of the art form in design. Problems of artistic expression of the modern subject environment. Tr. VNIITE. Ser. Technical aesthetics. Moscow: VNIITE, Vol. 45 [in Russian].

Стаття надійшла до редакиії 01.12.2018 p.

УДК 111.852:7.01

Безугла Руслана Іванівна, кандидат мистецтвознавства, доцент, доцент кафедри графічного дизайну Національної академії керівних кадрів культури і мистецтв orcid.org/0000-0003-1190-3646 r.bezuhla@gmail.com

\section{ДЕНДІЗМ І ГЛАМУР В КОНТЕКСТІ АНГЛІЙСЬКОЇ ХУДОЖНЬОЇ ЛІТЕРАТУРИ ХІХ СТОЛІТТЯ}

Мета роботи - виявити подібність між такими явищами, як гламур і дендизм. Стаття стала продовженням дослідження історичної континуальності візуальної демонстративності, зокрема гламуру який досліджується як амбівалентний художньо-мистецький феномен, що спрямований на уніфікацію символічних цінностей та естетичного ідеалу й містить певні сценарії поведінки. Методологія дослідження. Використання методу комплексного історико-мистецтвознавчого дослідження на основі принципів системності та історизму, дозволило розглядати дендизм і гламур як цілісні явища мистецтва. Наукова новизна. На підставі аналізу творів англійської художньої літератури обгрунтовується гіпотеза про історичну континуальність гламуру та його основної ознаки візуальної демонстративності, виявлена наявність загальних характерних рис між явищами дендизму та гламуру. Висновки. Доведено, що явища гламуру і дендизму є досить спорідненими феноменами, які об’єднує: візуальна демонстративність; штучність, театральність, ілюзорність; символізм та наявність певних кодів; маскування своєї сутності (в дендизмі, як і в гламурі, не має значення чим наповнений внутрішній світ людини, головним стає вміння «замаскувати», приховати справжні почуття, відчуття, емоції, думки тощо).

Ключові слова: дендизм, гламур, візуальна демонстративність, мистецтво, література.

(C) Безугла Р. I., 2019 